\title{
18. QUATERNARY DINOFLAGELLATE CYSTS FROM THE UPWELLING SYSTEM OFFSHORE PERU, HOLE 686B, ODP LEG 112 1
}

\author{
Jane Lewis, ${ }^{2}$ J. D. Dodge, ${ }^{2}$ and A. J. Powell ${ }^{3}$
}

\begin{abstract}
The dinoflagellate cyst assemblages from Quaternary sediments of Ocean Drilling Program (ODP) Hole 686B were determined. Results were interpreted as showing that under strong upwelling conditions assemblages are enriched with peridiniacean cysts, in contrast to weak upwelling situations where gonyaulacacean cysts become dominant. Results are discussed in relation to current planktonic assemblages and lifestyles. This possibly extends the use of dinoflagellates as paleoecological indicators in this region.
\end{abstract}

\section{INTRODUCTION}

During Leg 112, 10 sites were drilled on the Peruvian margin; one of the objectives of this leg was the elucidation of the history of upwelling on the Peruvian shelf. Along a north-south transect of the sites drilled (Trujillo Basin-West Pisco Basin), Quaternary upwelling sediments ranged from 14 to $>300 \mathrm{~m}$ thick. High sedimentation rates in the south reflect active subsidence of the Pisco Basin. Initial shipboard reports showed that the thick deposit of Quaternary sediments at Site 686 (the southernmost site) consists of alternating layers of laminated and bioturbated diatomaceous mud units relating to the cyclicity of changes in sea level, superimposed with smaller fluctuations that reflect a history of coastal upwelling of variable intensity at this site (von Huene et al., 1987).

The traditional biological notion of an upwelling area is one of increased primary productivity dominated by diatoms. However, although often neglected, dinoflagellates are also usually present in the water column in relatively low numbers (Blasco, 1971; Guillén et al., 1971; Rojas de Mendiola, 1974; Rojas de Mendiola and Estrada, 1976; Sukhanova et al., 1978; Ochoa and Gómez, 1981; Rojas de Mendiola, 1981; Sellner et al., 1983; Ochoa and Gómez, 1987). Although only a certain percentage of dinoflagellate species form cysts, and only a proportion of these are fossilizable, we might expect some record of their presence and fluctuations in the sediments.

Previous studies of dinoflagellate cyst assemblages from upwelling areas are limited; the most relevant is the survey by Wall et al. (1977), who investigated several areas, including a region off Peru. However, none of these studies involved examination of sediments laid down under different upwelling intensities over a period of time. A preliminary survey of several Leg 112 holes was conducted by Powell et al. (this volume); they concluded that ratios of certain cyst types may be useful indicators of upwelling strength. However, sampling gaps were wide and irregular, thus to investigate this relationship further, Site 686B was selected for examination in more detail because of its complete and expanded Quaternary succession. The purpose of this study was to ascertain how and in what respect the dinoflagellate cyst assemblages provide a record of upwelling events.

\footnotetext{
${ }^{1}$ Suess, E., von Huene, R., et al., Proc. ODP. Sci. Results, 112: College Station, TX (Ocean Drilling Program).

${ }^{2}$ Biology Department, Royal Holloway and Bedford New College, Egham Hill, Egham, Surrey TW20 0EX, United Kingdom.

${ }^{3}$ Stratigraphy Branch, BP Research Centre, Chertsey Road, Sunburyon-Thames, Middlesex TW16 7LN, United Kingdom.
}

\section{MATERIAL AND METHODS}

Site 686 is situated on the western side of the Pisco Basin at $1^{\circ} 28.81^{\prime} \mathrm{S}, 76^{\circ} 53.49^{\prime} \mathrm{W}$ in $447 \mathrm{~m}$ of water (Suess et al., 1988). Hole $686 \mathrm{~B}$ reached a total depth of 303 meters below seafloor (mbsf), and 33 samples from the top 103 mbsf (representing 0.87 m.y.) were analyzed. In the top $40 \mathrm{~m}$ the average sample spacing was $2.96 \mathrm{~m}$ (range, 1.5 to $9.99 \mathrm{~m}$ ), for the rest of the samples the spacing was $3.37 \mathrm{~m}$ (range, 1.5 to $7.47 \mathrm{~m}$ ); a complete list of samples analyzed is appended. Average sedimentation rates, determined from the Brunhes/Matuyama boundary and a radiometrically dated ash layer were between 55 and $60 \mathrm{~m} / \mathrm{m}$.y. for the upper $40 \mathrm{~m}$ of sediment and 180 $\mathrm{m} / \mathrm{m}$.y. for sediment between 40 and 154 mbsf (Suess et al., 1988). Therefore, in the top $40 \mathrm{~m}$ the sample spacing represents $0.05 \mathrm{~m} . \mathrm{y}$. and in the rest of the samples the spacing represents $0.02 \mathrm{~m}$.y. The samples worked here fall into the top three lithologic units described by Suess et al. (1988). Lithologic Unit I Core 112-686B-1H to Section 112-686B-3H-5, $30 \mathrm{~cm}$; depth, 0-24.3 mbsf) consisted of laminated diatomaceous mud having thin sand and silt layers. Unit II (Core 112-686B-3H-5 to Section 112-686B-11X-3, $40 \mathrm{~cm}$; depth, 24.3-97.4 mbsf) was largely burrowed diatomaceous mud having beds of sand and silt and Unit III (Sections 112-686B-11X-3, $40 \mathrm{~cm}$, to 112686B-16X-2; depth, 97.4-144.5 mbsf) was dominated by laminated diatomaceous mud.

Samples were processed using standard palynological techniques that involved treatment with hydrochloric and hydrofluoric acids and sieving (Powell et al., this volume). The unoxidized residue was mounted, and at least 200 cysts were counted for each sample, which gave only semiquantitative data, since the preparatory techniques employed (sieving stages) did not allow one to perform true quantitative estimates. Counts were made of cysts when $>50 \%$ of the cyst body was present. The diameters of all round brown (Brigantedinium spp.) cysts were measured to provide further information about this taxonomically difficult group. During this study, the genus Brigantedinium was not speciated because orientation or poor preservation frequently prevented this (see Note 3 , Table 1 ).

The peridiniacean/gonyaulacacean $(\mathrm{P} / \mathrm{G})$ cyst ratio was calculated using the formula, $P-G / P+G$, where $P=$ numbers of peridiniacean cysts and $G=$ numbers of gonyaulacacean cysts. A ratio approaching 1 implies dominance of peridiniacean cysts, and a ratio approaching -1 implies dominance of gonyaulacacean cysts. This $P / G$ ratio differs from the microplankton log ratio of Powell et al. (this volume), which is calculated differently, but the observed trends are the same. Foraminiferal test linings also were recorded, but are not considered here (see Powell et al., this volume).

\section{RESULTS}

A complete set of dinoflagellate cyst counts have been deposited in the stratigraphic library at British Petroleum, Sunbury-on-Thames (see A. J. Powell's address). Table 1 lists the species that were found, indicates their frequency, and gives brief taxonomic notes. A number of hitherto unde- 
Table 1. Cyst types found and their overall abundances in Hole 686B.

\begin{tabular}{|c|c|}
\hline Name & Frequency \\
\hline Spiniferites spp. & $F(R-F)$ \\
\hline S. bentorii (Rossignol) Wall & $\mathrm{R}$ \\
\hline S. delicatus Reid & $R(R-F)$ \\
\hline $\begin{array}{l}\text { S. hyperacanthus (Deflandre et Cookson) Cookson } \\
\text { and Eisenack }\end{array}$ & $R(R-F)$ \\
\hline S. membranaceus (Rossignol) Sarjeant & $R(R-F)$ \\
\hline S. mirabilis (Rossignol) Sarjeant & $F(R-A)$ \\
\hline S. pachyderma (Rossignol) Reid & $R(R-F)$ \\
\hline S. ramosus (Ehrenberg) Loeblich and Loeblich & $C(R-A)$ \\
\hline Nematosphaeropsis labyrinthea (Ostenfeld) Reid & $F(R-A)$ \\
\hline Impagidinium aculeatum (Wall) Harland & \\
\hline $\begin{array}{l}\text { Operculodinium centrocarpum (Deflandre and } \\
\text { Cookson) Wall }\end{array}$ & $F(R-C)$ \\
\hline Bitectatodinium tepikiense Wilson & $\mathbf{R}$ \\
\hline $\begin{array}{l}\text { Lingulodinium machaerophorum (Deflandre and } \\
\text { Cookson) Wall }\end{array}$ & $\mathbf{R}$ \\
\hline 'Scrippsiella spp. & $\mathrm{R}$ \\
\hline${ }^{2}$ Peridinium faeroense Paulsen & $\ddot{R}$ \\
\hline${ }^{3}$ Brigantedinium spp. & $A(F-A)$ \\
\hline Dubridinium caperatum Reid & $R(R-F)$ \\
\hline Quinquecuspis concretum (Reid) Harland & $R(R-F)$ \\
\hline Selenopemphix quanta (Bradford) Matsuoka & $\mathrm{F}(\mathrm{R}-\mathrm{C})$ \\
\hline $\begin{array}{l}\text { S. nephroides Benedek emend. Bujak emend. } \\
\text { Benedek and Sargeant }\end{array}$ & $R(R-F)$ \\
\hline Votadinium calvum Reid & $\mathbf{R}$ \\
\hline Trinovantedinium capitatum Reid & $R(R-F)$ \\
\hline $\begin{array}{l}{ }^{4} \text { Protoperidinium americanum (Gran and Braarud) } \\
\text { Balech }\end{array}$ & $\mathbf{R}$ \\
\hline${ }^{5}$ Spiny forms & $R(R-F)$ \\
\hline
\end{tabular}

${ }^{1}$ Two forms were found and ascribed to the genus Scrippsiella.

These are probably the inner lining of calcareous cysts.

2 A small organic cyst of this species was described by Dale (1977 and 1978).

3 Peridiniacean cysts of the round, brown type; because of orientation and poor preservation, speciation often was not possible. $B$, cariacoense (Wall) Reid and B. simplex (Wall) Reid were noted, however. Dinoflagellate cyst form C of Wall et al., 1977; Diplopsalis lenticula Bergh cyst, as described by Lewis (1985); and Diplopsalis orbicularis (Paulsen) Lebour, as described by Wall and Dale (1968) also are included in this category for morphological, rather than taxonomic, reasons.

${ }_{5}^{4}$ Cyst of this species, as described by Lewis and Dodge (1987).

${ }^{5}$ Grouped within this category are five unidentified forms of dinoflagellate cysts that probably have protoperidiniacean or gymnodinialean affinities. Included within these forms are dinoflagellate cyst forms A, B, and D of Wall et al. (1977).

$\mathrm{R}$ (Rare) $=<3 \% ; \mathrm{F}$ (Frequent) $=3 \%-5 \% ; \mathrm{C}$ (Common) $=$ $15 \%-30 \%$; A (Abundant) $=>30 \%$.

scribed forms were distinguished. More detailed taxonomic discussions and descriptions will follow. The dichotomous history of dinoflagellate research by palynologists and neontologists has led to two sets of nomenclature for cysts and motile cells. As far as possible in this paper, only the palynological cyst names have been used.

Depicted in Figure 1 are the percentages of the major species and groups recognized in Hole 686B. This record is most notable for its abundance of Brigantedinium spp. The mean size of Brigantedinium spp. increases from a minimum of 34 to $36 \mu \mathrm{m}$ at the top of the record to a maximum of 43 to $45 \mu \mathrm{m}$ in the middle part ( $40-60 \mathrm{mbsf})$, decreasing again in the bottom part to 37 to $41 \mu \mathrm{m}$. Three intervals of this group's dominance can be seen: from 0 to $15 \mathrm{mbsf}, 47$ to $65 \mathrm{mbsf}$, and 87 to 105 mbsf. In the two intervals where the proportion of Brigantedinium spp. in the assemblage is reduced, Spiniferites spp. are the replacement. In the youngest interval of most marked reduction (15-45 mbsf), Spiniferites ramosus and Nematosphaeropsis labyrinthea (a Spiniferites-type cyst) are the main replacement species. In the middle interval of Brigantedinium reduction (much less marked), Spiniferites mirabilis is the major replacement species, accompanied by $S$. pachyderma and $S$. ramosus. Operculodinium centrocarpum appears in greater proportions in the lower one-half of the section examined. Other cyst species of Protoperidinium reflect the two younger periods of Brigantedinium dominance and reduction, but downhole they appear uniformly distributed throughout the record. Of these species, Selenopemphix quanta (Protoperidinium conicum) was the most frequently recorded: its presence is most common in the lower one-half of the record. Of species found in percentages too low to be included in Figure 1, Impagidinium aculeatum is perhaps the most notable. This species occurred in very low percentages $(0.5 \%)$ in samples from $23.1,27.6$, and 66.6 mbsf and in similarly low percentages in three samples from deeper than 90 mbsf.

The graph of the P/G cyst ratio (Fig. 2) reflects the trends already noted within the stratigraphic distribution of Brigantedinium spp., i.e., three periods of high values interspersed with two periods of lower values. As previously noted, the two uppermost periods of enhanced and reduced values were much stronger than the following periods.

Figure 2 should be compared with the $\mathrm{U}_{\mathrm{k}}^{37}$ profile (Fig. ? of Farrimond et al., this volume). While both records are complex and somewhat 'noisy,' the two curves show an inverse relationship to each other (Spearman Rank correlation coefficient significant at the 0.05 level). That is, high values of the $\mathrm{P} / \mathrm{G}$ ratio are associated with low values of the $\mathrm{U}_{\mathrm{k}}^{37}$ index. Again, this is most clearly demonstrated in the youngest part of the succession.

\section{DISCUSSION}

Cyst formation in planktonic dinoflagellates is restricted to only a few genera, of which Gonyaulax and Protoperidinium predominate (Dale, 1983). How do the most recent cyst assemblages described here relate to records for modern phytoplankton assemblages? The most comprehensive, longterm phytoplankton survey available for the Peruvian area is that of Rojas de Mendiola (1981). Covering a 10-yr period, his survey shows that, in general, diatoms were the most abundant group of phytoplankton in all seasons. However, 65 species of dinoflagellates were observed: these were found to be most common in summer and autumn. Of the dinoflagellate species, approximately one-third were Protoperidinium species, one-fifth were Ceratium species, and only two Gonyaulax species were recorded. Rojas de Mendiola remarked on the relative consistency of the phytoplankton species composition, even under the variant conditions of " $\mathrm{El} \mathrm{Niño"}$ years. However, Ochoa and Gómez (1987) use dinoflagellates as indicators of different water masses, distinguishing El Niño years by the presence of warm-water equatorial species (e.g., Ceratium breve) and normal years by the presence of cold coastal-water species (e.g., Protoperidinium obtusum). Other studies suggest that dinoflagellate abundance increases with increasing water-column stability (Huntsman et al., 1981) and that higher proportions of dinoflagellates occur later in an upwelling succession (Sukhanova et al., 1978). Dinoflagellate blooms (usually Gymnodinium splendens) also have been observed in this area (Blasco, 1979; Rojas de Mendiola, 1979).

Table 2 compares phytoplankton species previously recorded offshore Peru with the cyst species we observed in the uppermost samples from Hole 686B. The phytoplankton reports are from a wider area of the Peruvian coast; therefore, data from the other holes examined during a preliminary study (Powell et al., this volume) are also included. A comparison of this type is limited by the state of our knowledge of cyst-theca relationships and taxonomic difficulties. In addition, the short time that some species are present in the phytoplankton make 


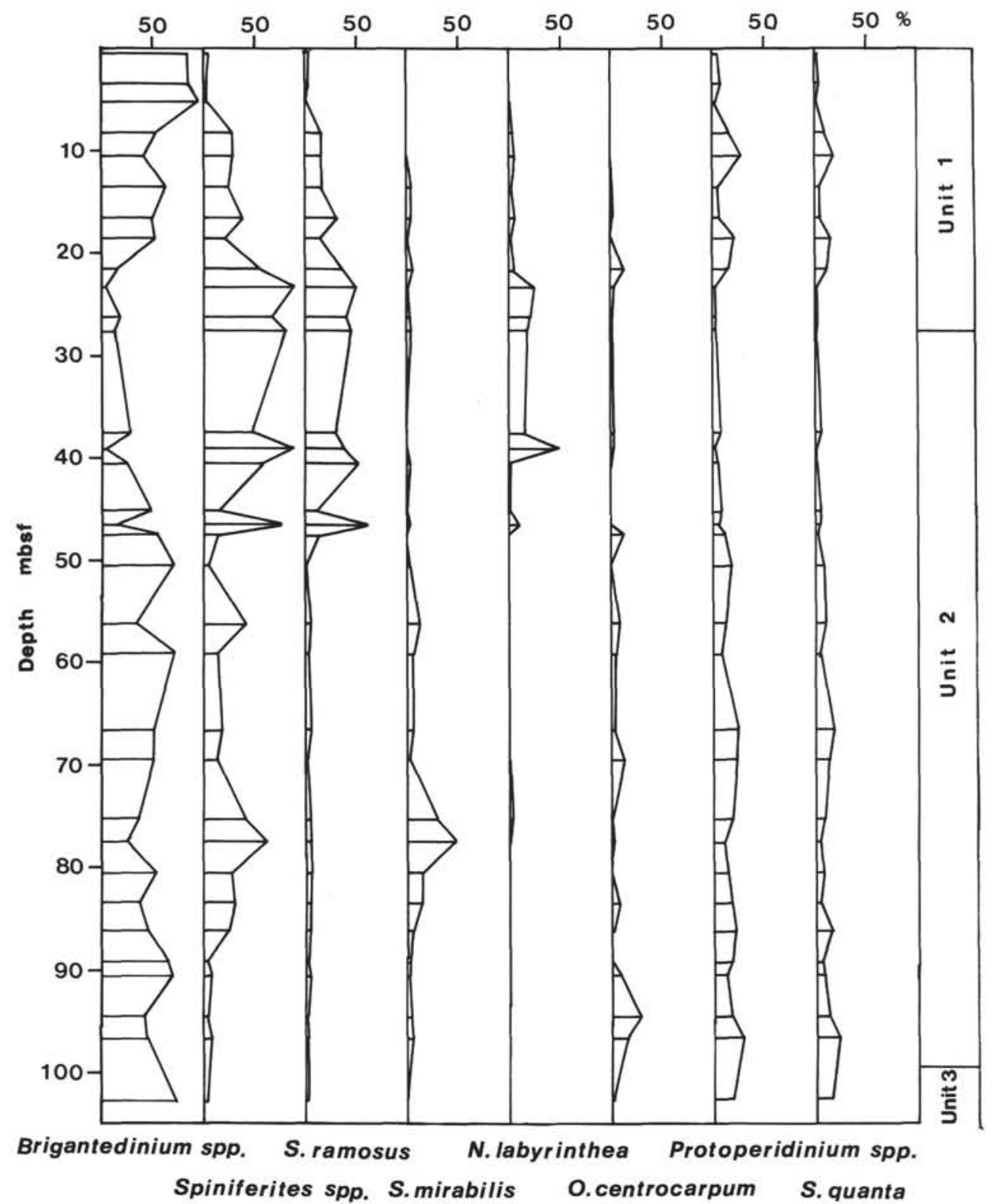

Figure 1. Dinoflagellate cyst biostratigraphy of Hole 686B, showing the proportions (\%) of various cyst species or groups. Spiniferites spp. includes the closely related $N$. labyrinthea; Protoperidinium spp. includes all Protoperidinium cysts other than the Brigantedinium spp. Lithologic units of Suess, von Huene, et al., (1988) are also shown.

their recovery in water samples unlikely. Two species noted in the phytoplankton studies, both of which are known to encyst, were not found by us. Of these two species it is likely that one of our unascribed spiny forms relates to Protoperidinium minutum. Cysts of Pyrophacus horologium were not noted here, although they have been found in nearshore sediments for this area (Wall and Dale, 1971). In addition, cysts of Protoperidinium avellana, $P$. conicoides, $P$. subinerme, $P$. oblongum, $P$. americanum, Gonyaulax grindleyi, Peridinium faeroense, and Zygabikodinium lenticulatum were found, but none of these were reported from the plankton. A surprising amount of agreement exists between the two records, with Protoperidinium species dominating both sets of data. With further study of cyst-theca relationships, more concurrence probably will be seen. For example, some of the Gymnodinium species noted in the phytoplankton for this area may produce cysts (Matsuoka, 1985). In addition, the variation in size of the Brigantedinium spp. suggests that a wide variety of species may be involved. While a number of species have been described in this genus (Reid, 1977), several archeopyle styles not previously observed were noted during this study. This implies that new cyst-theca relationships remain to be established for the genus Brigantedinium. Thus, the phytoplanktonic and stratigraphic records compliment one another, giving a picture for the modern upwelling situation of a great variety of Protoperidinium and Ceratium species that dominate the motile thecate dinoflagellate assemblages, with a scattered red tide of Gymnodinium species.

Lithologic Units I through III have been interpreted as representing alternating high- (I and III) and low- (II) stands of sea level (Suess, von Huene, et al., 1988, Table 3, p. 723). All the dinoflagellate species found in this study were classified as 


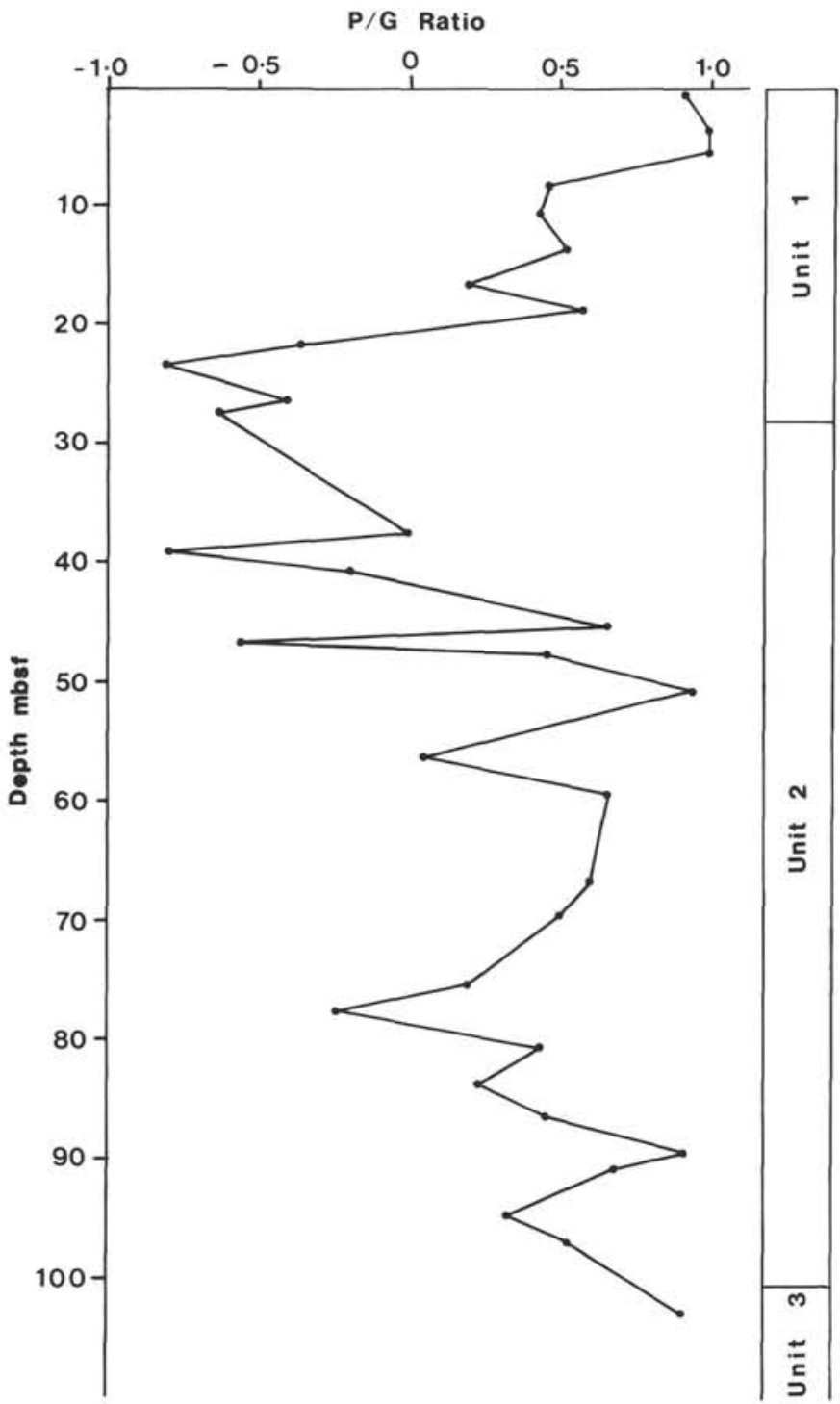

Figure 2. The $\mathrm{P} / \mathrm{G}$ ratio of Hole $686 \mathrm{~B}$, with the lithologic units of Suess, von Huene, et al., (1988).

neritic, with only Nematosphaeropsis labyrinthea and Impagodinium aculeatum having been described as having an outer neritic/oceanic distribution (Harland, 1983; Wall et al., 1977). The strongest indication of any change in sea level in the dinoflagellate record thus is between 22 and $40 \mathrm{mbsf}$, where both $N$. labyrinthea and I. aculeatum occur, implying outer neritic conditions. This lies mostly in the top of Unit II (lowstand of sea level), but $N$. labyrinthea also is present in lower proportions throughout the whole of Unit I (highstand of sea level). A similar antagonistic distribution of $N$. labyrinthe and Brigantedinium was noted by Turon and Londeix (1988) and was attributed to surface waters of differing salinities. The $P / G$ ratio does not show any relationship to the suggested changes in sea level. Therefore, in general the changes in sea level do not seem to be clearly reflected in the dinoflagellate cyst record. Perhaps these changes were not sufficient to have had a profound effect on the cyst assemblages. Indeed, when describing the depositional environment, Suess, von Huene, et al. (1988) suggested (from benthic foraminiferal assemblages) that Units III through I were deposited in middle to upper bathyal environments, perhaps at
Table 2. Species for which cyst-theca relationships are known and that have been mentioned in phytoplankton reports from the Peruvian area.

\begin{tabular}{|c|c|c|}
\hline $\begin{array}{l}\text { Species mentioned in } \\
\text { phytoplankton reports known to } \\
\text { produce cysts }\end{array}$ & $\begin{array}{c}\text { Cyst name } \\
\text { (where available) }\end{array}$ & $\begin{array}{l}\text { Cyst } \\
\text { found }\end{array}$ \\
\hline Gonyaulax spinifera 1,4 & $\begin{array}{l}\text { Spiniferites ramosus } \\
\text { S. mirabilis } \\
\text { S. membranaceus } \\
\text { Nematosphaeropsis labyrinthea }\end{array}$ & $\begin{array}{l}*+ \\
+ \\
+ \\
+\end{array}$ \\
\hline Protoperidinium claudicans 1 & Votadinium spinosum & + \\
\hline P. conicum $1,5,6$ & Selenopemphix quanta & ${ }^{*}+$ \\
\hline P. excentricum 1 & Brigantedinium sp. & ${ }^{*}+$ \\
\hline P. leonis 1,3 & Quinquecuspis concretum & *+ \\
\hline $\begin{array}{l}P . \text { minutum } 1,4,5 \\
P . \text { pentagonum } 1\end{array}$ & Trinovantedinium capitatum & + \\
\hline$P$. punctulatum 1 & Brigantedinium sp. & ${ }^{*+}+$ \\
\hline Diplopsalis lenticula $1,2,3,4,5$ & & $*+$ \\
\hline Scrippsiella trochoidea $1,2,3$ & & + \\
\hline Pyrophacus horologium 1,3 & & \\
\hline Polykrikos schwartzii 3 & & + \\
\hline
\end{tabular}

(1) Rojas de Mendiola, 1981. (2) Rojas de Mendiola and Estrada, 1976. (3) Blasco, 1971. (4) Strickland et al., 1969. (5) Rojas de Mendiola, 1974. (6) Ochoa and Gómez, 1987.

$*=$ From the shallowest three samples from Hole $686 \mathrm{~B}$.

$+=$ From the shallowest sample of each of the boreholes examined by Powell et al. (this volume).

slope depths comparable to the present depth of Site 686 . We suggest that some other factor has a more important role in determining the $\mathrm{P} / \mathrm{G}$ ratio.

Wall et al. (1977) showed that the effect of upwelling on cyst assemblages was an enrichment in peridiniacean species. They noted that this effect was most marked in the Peruvian region. This agrees well with our observations for the shallowest sediments investigated. Indeed, all of the unascribed species of Wall et al. (1977, Pl. 1) for this region were found during this study.

Undoubtedly, the most interesting aspect of this study is the relationship between the $\mathrm{U}_{\mathrm{k}}^{37}$ index and the $\mathrm{P} / \mathrm{G}$ ratio. $\mathrm{U}_{\mathrm{k}}^{37}$ is a molecular index of unsaturated ketones from coccolithophores. Changes in the $\mathrm{U}_{\mathrm{k}}^{37}$ index are related to surface-water temperature changes, with high values corresponding to high temperatures (Brassel et al., 1986). Times of low $U_{\mathrm{k}}^{37}$ values (lower temperatures of about $18^{\circ}-19^{\circ} \mathrm{C}$ ) may be indicative of intensified upwelling conditions in this locality (Farrimond et al., this volume). The low $\mathrm{U}_{\mathrm{k}}^{37}$ values can be seen to relate to high values of the $\mathrm{P} / \mathrm{G}$ ratio, i.e., dominance of the cyst assemblage by peridiniacean cysts. The reverse can also be seen, with high $\mathrm{U}_{\mathrm{k}}^{37}$ values (higher temperatures of about $25^{\circ} \mathrm{C}$, possibly representing weak upwelling in the locality) being related to low $\mathrm{P} / \mathrm{G}$ ratios (dominance of the cyst assemblage by gonyaulacacean cysts).

Most living peridiniacean dinoflagellates (Protoperidinium spp. and Diplopsalis spp.) are heterotrophic. Recent studies have shown that these forms feed mainly on diatoms (Gaines and Taylor, 1984; Jacobsen and Anderson, 1986). In seasonal terms, in temperate regions, these dinoflagellates usually occur in greatest numbers toward the end of the spring diatom bloom, presumably because they feed on diatoms. These heterotrophic species thus probably are able to flourish in an upwelling situation of high diatom abundance. The gonyaulacacean dinoflagellates, however, are photosynthetic (several are bloom formers, Anderson et al., 1985) and thrive in stratified water conditions. One would be unwise to infer higher production of a species from the cyst record because of the lack of quantitative data and because of over-representation of some species in the cyst record. However, changes in the proportions of cysts present imply changes in the populations producing them. We interpret the increase of the $P / G$ 
ratio as showing a predominance of Protoperidinium species present and to be indicative of an increase in intensity of upwelling. It follows that, a reduction of the $\mathrm{P} / \mathrm{G}$ ratio might be interpreted as a reduction in upwelling, or increased stratification. Thus, the stratigraphic distribution of dinoflagellate cysts might provide us with a useful record of upwelling history. Further study in other upwelling areas will be required to extend and refine our knowledge of these paleoecological relationships. One might find it particularly interesting to know whether any particular cyst species could act as markers for upwelling regimes. In other areas, dinoflagellate cysts have shown that they are useful markers for reconstructing climate from the Quaternary marine record (e.g., Harland, 1988). Our study furthers their possible application to this problem.

\section{SUMMARY}

1. The modern cyst assemblage found in samples from Site $686 \mathrm{~B}$ in the West Pisco Basin offshore Peru provides an extension of species information for the area. However, both the phytoplankton and cyst records show that for the dinoflagellates, peridiniacean cysts dominate under today's upwelling regime.

2. The $\mathrm{P} / \mathrm{G}$ ratio is interpreted as a reflection of upwelling intensity, high values (enrichment of peridiniacean species) during strong upwelling, and low values (enrichment of gonyaulacacean species) during periods of weak upwelling in this locality.

3. This research extends the potential usefulness of dinoflagellate cysts as markers for reconstructing paleoecology. Further research in other upwelling regions will be required to extend our knowledge and to ascertain whether any species act as markers for upwelling regimes.

\section{ACKNOWLEDGMENTS}

This study was conducted under NERC Grant No. GST/02/246. We thank P. Farrimond and G. Eglinton for permission to use their $\mathrm{U}_{k}^{37}$ data. This paper is published by permission of British Petroleum Co. plc.

\section{REFERENCES}

Anderson, D. M., White, A. W., and Baden, D. G. (Eds.) 1985. Toxic Dinoflagellates: New York (Elsevier).

Blasco, D., 1971. Composición y distribución del fitoplancton en la región del afloramiento de las costas peruanas. Inv. Pesq., 35:61112.

1979. Changes of the surface distribution of a dinoflagellate bloom off the Peru coast related to the time of day. In Taylor, D. L., and Seliger, H. H. (Eds.), Toxic Dinoflagellate Blooms: North-Holland (Elsevier), 209-214.

Brassel, S. C., Eglinton, G., Marlowe, I. T., Pflaumann, U., and Sarnthein, M., 1986. Molecular stratigraphy: a new tool for climatic assessment. Nature, 320:129-133.

Dale, B., 1983. Dinoflagellate resting cysts: "benthic plankton." In Fryxell, G. A. (Ed.), Survival Strategies of the Algae: Cambridge (Cambridge Univ. Press), 69-136.

Gaines, G., and Taylor, F. J. R., 1984. Extracellular digestion in marine dinoflagellates. J. Plankton Res., 6:1057-1061.

Guillén, O., Rojas de Mendiola, B., and Izaguirre de Rondan, R., 1971. Primary productivity and phytoplankton in the coastal Peruvian waters. In Costlow, J. D. (Ed.), Fertility of the Sea: London (Gordon and Breach), 157-185.

Harland, R., 1988. Dinoflagellates, their cysts and Quaternary stratigraphy. New Phytol., 108:111-120.
Huntsman, S. A., Brink, K. H., Barber, R. T., and Blasco, D., 1981. The role of circulation and stability in controlling the relative abundance of dinoflagellates and diatoms over the Peru shelf. In Richards, F. A. (Ed.), Coastal Upwelling: Washington (Am. Geophys. Un.), 357-365.

Jacobsen, D. M., and Anderson, D. M., 1986. Thecate heterotrophic dinoflagellates: feeding behavior and mechanisms. J. Phycol., 22:249-258.

Lewis, J. M., 1985. The ecology and taxonomy of marine dinoflagellates in Scottish sea-lochs [Ph.D. dissert.]. Univ. of London.

Lewis, J., and Dodge, J. D., 1987. The cyst-theca relationship of Protoperidinium americanum (Gran and Braarud) Balech. J. Micropalaeontol., 6:113-121.

Matsuoka, K., 1985. Archeopyle structure in modern gymnodinialean dinoflagellate cysts. Rev. Palaeobot. Palynol., 44:217-231.

Ochoa, N. L., and Gómez, O. C., 1981. Variaciones del fitoplancton en el área de Chimbote durante 1977. Bol. Inst. Mar. Peru, Vol. Extraordinario, 1981:119-129.

1987. Dinoflagellates as indicators of watermasses during El Niño, 1982-1983. J. of Geophys. Res., 92:14355-14367.

Reid, P. C., 1977. Peridiniacean and Glenodiniacean dinoflagellate cysts from the British Isles. Nova Hedw., 29:429-463.

Rojas de Mendiola, B., 1974. Food of the larval Anchoveta Engraulis ringens J. In Blaxter, J. H. S. (Ed.), The Early Life History of Fish: Berlin-Heidelberg (Springer-Verlag), 277-285.

, 1979. Red tide along the Peruvian coast. In Taylor, D. L., and Seliger, H. H. (Eds.), Toxic Dinoflagellate Blooms: NorthHolland (Elsevier), 183-190.

1981. Seasonal phytoplankton distribution along the Peruvian coast. In Richards, F. A. (Ed.), Coastal Upwelling: Washington (Am. Geophys. Un.), 348-356.

Rojas de Mendiola, B., and Estrada, M., 1976. El fitoplancton en el area de Pimentel Verano de 1972. Inv. Pesq., 40:463-490.

Sellner, K. G., Hendrikson, P., and Ochoa, N., 1983. Relationships between the chemical composition of particulate organic matter and phytoplankton distributions in recently upwelled waters of Peru. In Suess, E., and Thiede, J. (Eds.), Coastal Upwelling: Its Sedimentary Record. Responses of the Sedimentary Regime to Present Coastal Upwelling: New York (Plenum Press), 273-287.

Strickland, J. D. H., Eppley, R. W., and Rojas de Mendiola, B., 1969. Phytoplankton populations, nutrients, and photosynthesis in Peruvian coastal waters. Bol. Inst. Mar. Peru, 2:1-45.

Sukhanova, I. N., Konovalova, G. V., and Rat'kova, T. N., 1978. Phytoplankton numbers and species structure in the Peruvian upwelling region. Oceanology, 18:72-76.

Suess, E., von Huene, R., et al., 1988. Proc. ODP., Sci. Results, 112: College Station, TX (Ocean Drilling Program).

Turon, J.-L., and Londeix, L., 1988. Les assemblages de kystes de dinoflagellés en méditerranée occidentale (Mer D'Alboran) mise en évidence de l'évolution des paléoenvironnments depuis le dernier maximum glaciaire. Bull. Centres Rech. Explor.-Prod. Elf-Aquitaine, 12:313-344.

von Huene, R., Suess, E., and Emeis, K-C., 1987. Convergent tectonics and coastal upwelling: a history of the Peru continental margin. Episodes, 10:87-93.

Wall, D., and Dale, B., 1968. Modern dinoflagellate cysts and evolution of the Peridiniales. Micropaleontology, 14:265-304. 1971. A reconsideration of living and fossil Pyrophacus Stein, 1883 (Dinophyceae). J. Phycol., 7:221-235.

Wall, D., Dale, B., Lohmann, G. P., and Smith, W. K., 1977. The environmental and climatic distribution of dinoflagellate cysts in modern marine sediments from regions in the North and South Atlantic oceans and adjacent seas. Mar. Micropaleontol., 2:121200.

Date of initial receipt: 7 September 1988

Date of acceptance: 1 May 1979

MS 112B-162 
APPENDIX

Samples Analyzed for Quaternary Dinoflagellate Cysts

\begin{tabular}{c}
\hline Core, section, interval $(\mathrm{cm})$ \\
\hline $112-686 \mathrm{~B}-1 \mathrm{H}-1,64-66$ \\
$1 \mathrm{H}-3,64-66$ \\
$1 \mathrm{H}-4,64-66$ \\
$1 \mathrm{H}-6,64-66$ \\
$2 \mathrm{H}-2,40-43$ \\
$2 \mathrm{H}-4,40-43$ \\
$2 \mathrm{H}-6,40-43$ \\
$3 \mathrm{H}-1,56-58$ \\
$3 \mathrm{H}-3,56-58$ \\
$3 \mathrm{H}-4,56-58$ \\
$3 \mathrm{H}-6,56-58$ \\
$4 \mathrm{H}-1,14-17$ \\
$5 \mathrm{H}-1,59-61$ \\
$5 \mathrm{H}-2,59-61$ \\
$5 \mathrm{H}-3,59-61$ \\
$5 \mathrm{H}-6,59-61$ \\
$5 \mathrm{H}-7,59-61$ \\
$112-686 \mathrm{~B}-6 \mathrm{X}-1,91-95$ \\
$6 \mathrm{X}-3,91-95$ \\
$7 \mathrm{X}-1,13-15$ \\
$7 \mathrm{X}-3,13-15$ \\
$8 \mathrm{X}-1,110-114$ \\
$8 \mathrm{X}-3,110-114$ \\
$9 \mathrm{X}-1,13-15$ \\
$9 \mathrm{X}-3,61-63$ \\
$9 \mathrm{X}-5,61-63$ \\
$9 \mathrm{X}-7,61-63$ \\
$10 \mathrm{X}-2,18-22$ \\
$10 \mathrm{X}-4,18-22$ \\
$10 \mathrm{X}-5,18-22$ \\
$11 \mathrm{X}-1,56-58$ \\
$11 \mathrm{X}-3,56-58$ \\
$11 \mathrm{X}-7,56-58$ \\
\end{tabular}

